\title{
Precision study of satellite levelling with using various models of geoid
}

\author{
Anna Buczyńska, ${ }^{1, *}$ \\ ${ }^{1}$ Wroclaw University of Science and Technology, Faculty of Geoengineering, Mining and Geology, 27 Wyb. Wyspiańskiego St., \\ 50-370 Wroclaw, Poland
}

\begin{abstract}
The main purpose of this study is comparison of orthometric heights of measuring points and the accuracy of these heights depending on selected geoid model and measurement method. In addition, for better understanding of the essence of conducted research, paper provides information about:

- geoid and other surfaces used in geodesy to describe the terrestrial globe,

- modelling methods of equipotential surfaces and data that can be used to develop them,

- the most important geoid models developed for the area of Poland and the world,

- the technique of determining the orthometric heights using various measuring methods. Heights of two measuring points, located on the premises of Wrocław University of Science and Technology, were determined to achieve thesis statement. The scope of the study is limited to determining the orthometric heights of points for three global geoid models and four geoid models developed for the area of Poland. Among the selected equipotential surfaces were: geoida niwelacyjna 2000, GUGiK 2001, GEOIDPOL 2008A/C/CN, PL-GEOID-2011, OSU91, EGM96 and EGM2008.
\end{abstract}

\section{Introduction}

Due to the rapid development of satellite measurement techniques, it is increasingly common to replace classical measurement methods with satellite measurements. This is due to advantages of satellite methods such as short time of measurement and low cost of carrying it out. However, the basic issue of analyzed case is an accuracy of heights achieved from measurements that is currently object of many studies.

Precision study of satellite levelling is the aim of this publication. In paper will be presented comparison of orthometric heights achieved from satellite and precise levelling in relation to various models of geoid.

\section{Characteristic of selected geoid models}

The matter on our globe cannot be distributed in a uniform way, as if it were in the case of a sphere. The whirling movement of the Earth around its own axis causes its flattening near the pole [1]. Although the shape of the Earth cannot be defined as a rotational ellipsoid, due to its mathematical description, it is a widely used solid in the field of geodesy. The parameters of the current WGS 84 ellipsoid are shown in Table 1.
Table 1. Parameters of the WGS 84 ellipsoid [2].

\begin{tabular}{|c|c|c|}
\hline Parameter name & Parameter value & Unit \\
\hline $\begin{array}{c}\text { Longer axis of the } \\
\text { ellipsoid } a\end{array}$ & 6378137.000 & $\mathrm{~m}$ \\
\hline Angular velocity $\omega$ & $7.292115 \times 10^{-5}$ & $\mathrm{rad} \mathrm{s}^{-1}$ \\
\hline Flattening $f$ & $1 / 298.257223563$ & - \\
\hline $\begin{array}{c}\text { Geocentric } \\
\text { gravitational } \\
\text { constant } G M\end{array}$ & 398600.4418 & $\mathrm{~km}^{3} \mathrm{~s}^{-2}$ \\
\hline
\end{tabular}

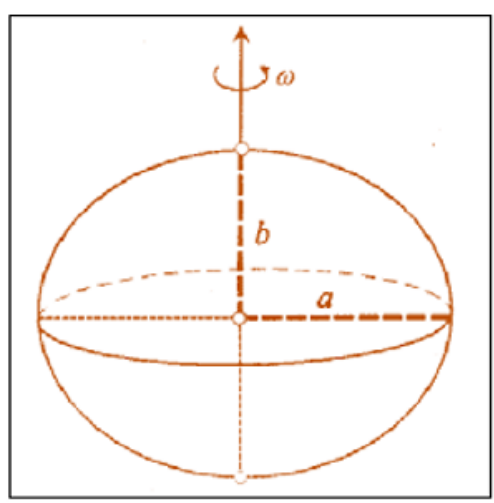

Fig. 1. Rotational ellipsoid [1].

First time in history the definition of geoid was formulated in 1873 by German mathematician, Johann Listing. He claimed that this solid could be defined as an

\footnotetext{
* Corresponding author: anna.buczynska@pwr.edu.pl
} 
extension of the average surface of seas and oceans at rest under lands [3]. Somewhat different definition was proposed on the website of ASG EUPOS system [4], where we can read that: ,geoid is theoretical surface of constant geopotential that corresponds with surface of seas and oceans and is contractually extended under lands". The courses of the geoid and ellipsoid are shown in Fig. 2.

Below there is presented the other important information about geoid:

a) the force of gravity is perpendicular to this surface at all points,

b) it is characterized by irregular shape that cannot be described mathematically,

c) geoid is not a constant surface because it undergoes periodic changes resulting from tides and winds,

d) on account of irregular shape of geoid, it cannot be used as a reference plane for situational surveys but it is a reference for measurements of altitude,

e) in academic literature there is also definition of geoid zero. That surface gets through the average surface of seas and oceans and was determined at a point through many years of observations. Introduction of geoid zero arises from the fact that depending on the value of geopotential, we can create many different equipotential surfaces;

f) geoid is used as a reference plane for orthometric heights [3].

Dozens of geoid models have been developed to this moment that differ in many ways. An accuracy of geoid models resulting from used method of modelling and source data should be indicated as the basic differences between them. The main methods of modelling are:

- Stokes' integral method - classical method of geoid modelling based on the solution to the boundary problem [5];

- fast Fourier transform (FFT) - technics used to compute Stokes' integral in the case of a regular distribution of gravity anomalies [6];

- Molodenski's integral method - it is the solution to the boundary problem, same as Stokes' integral method, although this technics misses out the influence of topographic mass distribution inside the Earth. Measured values of geopotential and boundary conditions are reduced relative to the boundary surface called telluroid [7];

- least squares method - in this method intervals between geoid and ellipsoid are computed using system of linear equations the number of which is equal to the number of observations [8];

- remove-compute-restore method - method commonly used to develop regional gravimetric geoid models. Technics enables to generate regional equipotential surfaces characterized by very high accuracy with using gravity data only for the modelled area [6].

Data used in all the above-mentioned methods are:

- $\quad$ astronomical and gravimetric deviations of the lines of force of gravity,

- ellipsoidal heights measured by satellite techniques GNSS,
- data achieved by precise levelling, topographic data [9].

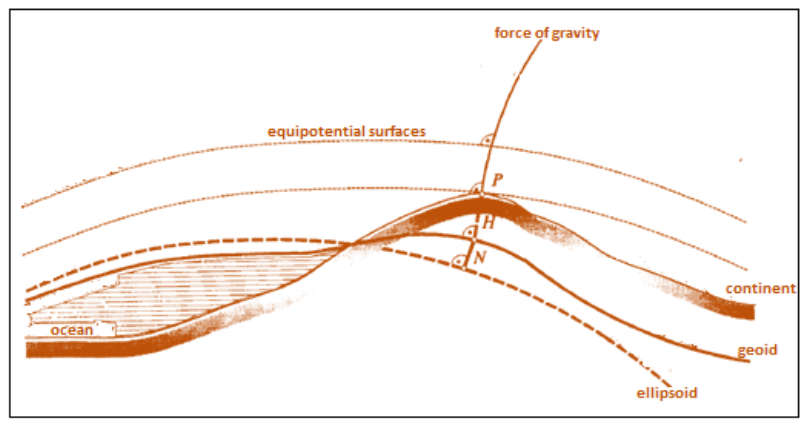

Fig. 2. The courses of the geoid and ellipsoid [1].

This paragraph presents classification of the equipotential surfaces published on the website of the Institute of Geodesy and Cartography. This classification was made due to the source data used in the modelling of the equipotential surface as well as the method of its creation. Thus, the following geoid models were distinguished:

- astronomical-geodetic,

- astronomical-gravimetric,

- gravimetric,

- satellite-levelling,

- gravimetric fitted,

- integrated.

Among the resulting geoid models there are less accurate surfaces, in region of a few $\mathrm{dm}$ and surfaces that are characterized by high accuracy, in region of a few $\mathrm{cm}$. The other factor which differs mentioned surfaces is numeric character of model. In the end there is necessary to write that geoid models can be divided according to the area which they cover. Taking the last difference into account we can distinguish global geoid models, that cover large areas of the globe and regional models.

Tables 2 and 3 contain a short characteristic of regional and global geoid models respectively that were used for this study.

\section{Characteristic of measuring techniques and measuring area}

The measured points were located in the eastern part of the Wrocław city, on the premises of Wrocław University of Science and Technology at $\mathrm{Na}$ Grobli street no. 13/15. As shown in Fig. 3 these points reside in the parking lot located behind the Geocentre building and distance between them is not greater than $100 \mathrm{~m}$. In the nearest neighborhood, there are no devices emitting electromagnetic waves that can cause interference. None of points is situated near trees. It is important to point out that during measurements there were many cars around which could cause partial reflection of satellite signal. 
Table 2. Characteristics of regional geoid models used in study [10-12].

\begin{tabular}{|c|c|c|c|}
\hline $\begin{array}{c}\text { Name of } \\
\text { model }\end{array}$ & $\begin{array}{c}\text { Type of } \\
\text { geoid model }\end{array}$ & Source data & Other information \\
\hline $\begin{array}{c}\text { Geoida } \\
\text { niwelacyjna } \\
2000 \\
\end{array}$ & $\begin{array}{l}\text { satellite- } \\
\text { levelling }\end{array}$ & $\begin{array}{c}\text { height points of the networks: EUREF- } \\
\text { POL, POLREF, EUVN, WSSG and } \\
\text { Tatry }\end{array}$ & $\begin{array}{l}\text {-developed for the surfaces about min curvature of the } \\
\text { grid } 0.01^{\circ} \times 0.01^{\circ}\end{array}$ \\
\hline $\begin{array}{c}\text { Geoida } \\
\text { niwelacyjna } \\
2001 \\
\text { (GUGiK } \\
\text { 2001) }\end{array}$ & $\begin{array}{l}\text { gravimetric } \\
\text { fitted }\end{array}$ & $\begin{array}{l}\text { gravimetric quasigeoid model quasi97b } \\
\text { and height points of the networks: } \\
\text { EUREF-POL, POLREF, EUVN, WSSG } \\
\text { and Tatry }\end{array}$ & $\begin{array}{l}\text { - model was created by fitting gravimetric quasigeoid } \\
\text { model quasi97b to the satellite-levelling geoid model } \\
\text { QGEOID'PL } 01 \text {; } \\
\text { - developed for the surfaces of the grid 1' x 1'; } \\
\text { - model was computed by using spline functions of } \\
\text { degree } 3 \text {; } \\
\text { - accuracy of this model was done at } 140 \text { points of the } \\
\text { traverse with result } \pm 1.8 \mathrm{~cm}\end{array}$ \\
\hline $\begin{array}{l}\text { GEOIDPOL } \\
-2008\end{array}$ & $\begin{array}{l}\text { satellite- } \\
\text { levelling }\end{array}$ & $\begin{array}{l}\text { global geoid model EGM2008 and a } \\
\text { collection of } 400 \text { points of the satellite- } \\
\text { levelling networks: EUVN, EUREF- } \\
\text { POL and POLREF }\end{array}$ & $\begin{array}{l}\text { - model was created by fitting global geopotential } \\
\text { model to the points of satellite-levelling network; } \\
\text { - accuracy } \pm 1.7 \mathrm{~cm}\end{array}$ \\
\hline $\begin{array}{l}\text { PL-geoid } \\
2011\end{array}$ & $\begin{array}{l}\text { satellite- } \\
\text { levelling }\end{array}$ & $\begin{array}{l}\text { global geoid model EGM2008 and a } \\
\text { collection of } 570 \text { points of the satellite- } \\
\text { levelling networks: ASG EUPOS, } \\
\text { EUVN, EUREF-POL and POLREF }\end{array}$ & $\begin{array}{l}\text { - model was created by fitting global geopotential } \\
\text { model to the points of satellite-levelling network; } \\
\text { - accuracy } \pm 1.5 \mathrm{~cm}\end{array}$ \\
\hline
\end{tabular}

Table 3. Characteristics of global geoid models used in study [13-15].

\begin{tabular}{|c|c|}
\hline $\begin{array}{l}\text { Name of } \\
\text { model }\end{array}$ & Basic information \\
\hline EGM2008 & 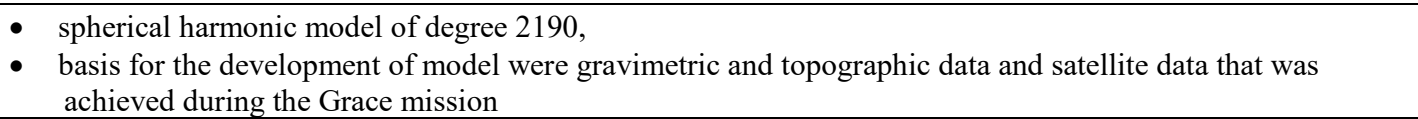 \\
\hline EGM96 & $\begin{array}{l}\text { - spherical harmonic model of degree 360; model was computed by using data: } \\
\text { a.collection of gravimetric anomalies of the grid 30' x 30', which was completed by data come from South } \\
\text { America, countries of Africa, Canada, Russia and areas covered with internal ice; } \\
\text { b.collection of altimetric data achieved from satellite: GEOSAT, TOPEX/POSEIDON and ERS-1; } \\
\text { c.global geopotential model EGM96S. }\end{array}$ \\
\hline OSU91 & $\begin{array}{l}\text { - spherical harmonic model of degree } 360 \text {, } \\
\text { - basic data which were necessary to compute this model were: collection of Faye's anomalies of the grid } 1^{\circ} \mathrm{x} \\
1^{\circ} \text {, global geopotential model GEMT2 and altimetric data achieved for areas of less than } 60 \text { degrees of } \\
\text { latitude, area of Mediterranean Sea and the other areas which were characterized by good signal frequency. }\end{array}$ \\
\hline
\end{tabular}



Fig. 3. Location of measuring points $(\mathrm{Z} 1, \mathrm{Z} 2)$ and base benchmarks of precise levelling network $(\mathrm{F}, \mathrm{G})$. 
Measuring points $\mathrm{Z} 1$ and $\mathrm{Z} 2$ are concrete pillars permanently attached to the ground with a height of 1.14 $\mathrm{m}$ and a diameter of $0.32 \mathrm{~m}$. Each of them allows to screw GPS receiver, which means that accidental change of instrument position (on account of momentary inattention of observer or change of weather) is insignificant. One of the measuring points is presented in Fig. 4.

The above-mentioned points were measured using two techniques. The static technique has been chosen, as the most accurate among existing satellite measurement methods. Static technique is one of the method of relative satellite measurements ergo the measurements in which at least two receivers execute synchronous observations of the same satellite. While effectuating mensuration, the receivers are motionless in regard of each other. The span of one observation session is relatively long and it depends on accuracy that is desirable to achieve as well as on the distance between measuring points. In literature, information that the durance of measurement oscillates between a few hours and several days is the one that is found the most frequently. Anticipated relative accuracy for this specific method equals \pm 1 asl of the length of the determined vector [16].

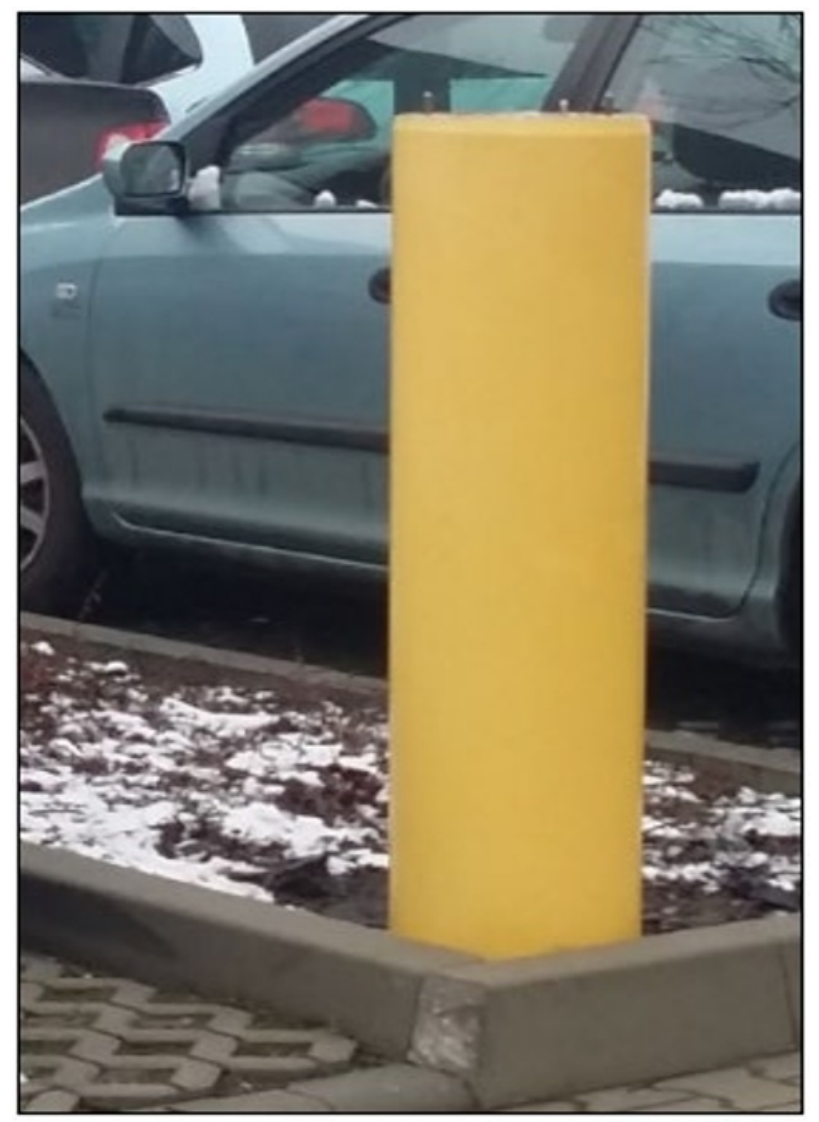

Fig. 4. Measuring point Z1.

Precise levelling was used as a second measurement method to achieve thesis statement. Measurement was taken according to polish decrees [17] and [18].
Table 4. Basic information about measurement of satellite levelling.

\begin{tabular}{|c|c|}
\hline $\begin{array}{c}\text { Date of } \\
\text { measurement: }\end{array}$ & Trimble TSC3 \\
\hline Model of receiver & GPS Trimble R6 Internal \\
\hline Model of antenna & - $\begin{array}{c}\text { station of ASG-EUPOS } \\
\text { network: WROC, } \\
\text { Btation of network TPI } \\
\text { Beasuring points }\end{array}$ \\
\hline $\begin{array}{c}\text { Time of } \\
\text { measurement }\end{array}$ & 90 min \\
\hline $\begin{array}{c}\text { Interval of data } \\
\text { recording }\end{array}$ & $2 \mathrm{~s}$ \\
\hline $\begin{array}{c}\text { The minimum } \\
\text { number of observed } \\
\text { satellites }\end{array}$ & 4 \\
\hline $\begin{array}{c}\text { The minimum height } \\
\text { of the satellite above } \\
\text { the horizon }\end{array}$ & $15^{0}$ \\
\hline $\begin{array}{c}\text { The maximum value } \\
\text { of PDOP factor }\end{array}$ & 6 \\
\hline
\end{tabular}

Recommendations that were used during levelling measurement are:

- difference in elevation between base benchmarks was determined twice: there and back;

- elevation at all measuring positions was determined twice by using direct levelling. Difference between both measurement results was not greater than 0.24 $\mathrm{mm}$ which is permissible value indicated in [17]. The second measurement was taken after change in the height of the target axis of the instrument;

- measuring positions were chosen at halfway between two measuring points;

- distances between measuring positions and measuring points were not longer than $40 \mathrm{~m}$;

- length of measuring sections did not exceed the distance of $80 \mathrm{~m}$;

- level rods were placed on turning plates at transition points;

- measurement was made in conditions of temperate wind and temperature, with good visibility of level rods;

- instrument and level rods were placed on stable ground, in the surroundings where there are no objects emitting warmth;

- height of the target axis of the instrument was always higher than $1.5 \mathrm{~m}$;

- levelling line consisted of even number of measuring stations. This solution allowed to observe the same level rod at the start and the end point. At its back, second, not-observed level rod was placed to the benchmarks $[17,18]$.

Detailed information about taken measurements is in Table 5. 
Table 5. Basic information about measurement of precise levelling.

\begin{tabular}{|c|c|}
\hline Date of measurement & $23.05 .2015 \mathrm{r}$. \\
\hline Name of instrument & $\begin{array}{c}\text { Digital level Trimble DiNi 0.3 } \\
\text { Serial number: 734253 }\end{array}$ \\
\hline Other equipment & Level rods, turning plates \\
\hline Base benchmarks & $\mathrm{G}, \mathrm{F}$ \\
\hline $\begin{array}{c}\text { Number of } \\
\text { measuring sections }\end{array}$ & 4 \\
\hline $\begin{array}{c}\text { Length of levelling } \\
\text { line }\end{array}$ & $0.150 \mathrm{~km}$ \\
\hline $\begin{array}{c}\text { Number of } \\
\text { measuring stations }\end{array}$ & 4 \\
\hline Wind flow velocity & $5 \mathrm{~m} / \mathrm{s}$ \\
\hline Temperature & $25^{\circ}$ \\
\hline
\end{tabular}

\section{Results}

The results presented in this chapter have been obtained by means of manipulating the data drawn from satellite levelling and classic measurement. In the first instance, the heights for which global geoids constitute reference surface will be discussed. At the first stage, the files obtained from GPS receiver were converted into format of exchanging data independent on receiver RINEX (Receiver Independent Exchange), and subsequently imported to Trimble Business Center. After preliminary verification (deleting incomplete and discontinuous data as well as data for which time span of observation was an extremely short) the establishing of vectors between measurement points and two points constituting the base points of network were proceeded. As a result 12 vectors with the „Fixed" type solution have been procured. Specific information on established vectors is comprised by Table 6 .

Table 6. Comparison of established vectors in Trimble Business Center software.

\begin{tabular}{|c|c|c|c|c|c|}
\hline $\begin{array}{c}\text { From } \\
\text { point }\end{array}$ & $\begin{array}{c}\text { To } \\
\text { point }\end{array}$ & PDOP & RMS & $\begin{array}{c}\text { Vertical } \\
\text { Precision } \\
{[\mathbf{m}]}\end{array}$ & $\begin{array}{c}\text { Vector } \\
\text { Length } \\
{[\mathbf{m}]}\end{array}$ \\
\hline PRUS & $\mathrm{Z} 1$ & 1.75 & 0.015 & 0.010 & 31005.92 \\
\hline PRUS & $\mathrm{Z} 1$ & 1.70 & 0.009 & 0.016 & 31005.92 \\
\hline PRUS & $\mathrm{Z} 2$ & 1.71 & 0.007 & 0.011 & 30967.16 \\
\hline PRUS & $\mathrm{Z} 2$ & 2.04 & 0.007 & 0.015 & 30967.17 \\
\hline WROC & PRUS & 1.44 & 0.001 & 0.009 & 30106.68 \\
\hline WROC & PRUS & 1.89 & 0.001 & 0.009 & 30106.67 \\
\hline WROC & Z1 & 2.00 & 0.002 & 0.005 & 1142.47 \\
\hline WROC & $\mathrm{Z} 1$ & 1.75 & 0.001 & 0.003 & 1142.48 \\
\hline WROC & $\mathrm{Z} 2$ & 2.12 & 0.001 & 0.003 & 1094.74 \\
\hline WROC & $\mathrm{Z} 2$ & 2.04 & 0.001 & 0.003 & 1094.74 \\
\hline Z1 & $\mathrm{Z} 2$ & 2.04 & 0.002 & 0.003 & 47.76 \\
\hline Z1 & $\mathrm{Z} 2$ & 2.01 & 0.003 & 0.005 & 47.76 \\
\hline
\end{tabular}

Lastly, the network was adjusted in order to estimate and eliminate both serious and arbitrary blunders as well as to minimize the adjustments implemented to observation and to obtain crucial data enabling determining the accuracy of designated heights. The adjustment was conducted three times by means of method of least squares, every time the settings of the global geoid model: OSU91, EGM96 and EGM2008 were changed. For each adjustment, the value of Network Reference Factor was akin to unity what proclaims the accuracy and the correctness of measurement data (Network Reference Factor indicates whether chance error of observation are acceptable and whether they are correspondent to estimated standard errors for such observations). As a result of an adjustment, the orthometric heights of $\mathrm{Z} 1$ and $\mathrm{Z} 2$ points referred to the global geoid models and accuracies of these heights have been obtained.

At the second stage, the ellipsoidal heights sourced from Trimble Business Center have been applied as input data in order to calculate the orthometric heights of measurement points referred to the regional geoid models as well as the accuracy of these heights. The crucial conversions were executed in Transmutation software that has built-in models wrought for the area of Poland. On the basis of a relevant model of equipotential surface and bilinear interpolation, the programme determines the distance between geoid and ellipsoid and thereafter it is subtracted from designated ellipsoidal height of a point in order to obtain the orthometric height [19].

At the last stage, on the basis of the results of the precise levelling, the orthometric heights of Z1 and Z2 points along with accuracy of these heights have been designated. The heights calculated on the basis of the height levelling log have been subsequently adjusted by means of least squares method due to C-Geo software. The measured levelling network was marked by the average error of observation that equals $0.98 \mathrm{~mm} / \mathrm{km}$. Table 7. contains adjusted heights $\mathrm{H}$ of measuring points and their accuracies $\Delta \mathrm{H}$ while Table 8 . is presenting detailed information about adjusted elevations $\mathrm{Dh}$ and accuracy $\Delta \mathrm{Dh}$ of them.

Table 7. Comparison of adjusted height in regard from the precise levelling.

\begin{tabular}{|c|c|c|}
\hline Point & $\mathbf{H}[\mathbf{m}]$ & $\mathbf{\Delta H}[\mathbf{m m}]$ \\
\hline $\mathrm{F}$ & 119.760 & 0.00 \\
\hline $\mathrm{G}$ & 119.727 & 0.00 \\
\hline $\mathrm{Z} 1$ & 120.547 & 0.13 \\
\hline $\mathrm{Z} 2$ & 120.469 & 0.12 \\
\hline
\end{tabular}

Table 8. Comparison of adjusted elevations from the precise levelling.

\begin{tabular}{|c|c|c|c|}
\hline From point & To point & $\mathbf{D h}[\mathbf{m}]$ & $\boldsymbol{\Delta} \mathbf{D h}[\mathbf{m m}]$ \\
\hline $\mathrm{G}$ & $\mathrm{Z} 2$ & -0.1090 & 0.12 \\
\hline $\mathrm{Z} 2$ & $\mathrm{Z} 1$ & 0.0779 & 0.12 \\
\hline $\mathrm{Z} 1$ & $\dot{\mathrm{z}} .1$ & -0.5117 & 0.10 \\
\hline$\dot{\mathrm{z}} .1$. & $\mathrm{F}$ & 0.5753 & 0.10 \\
\hline
\end{tabular}


The orthometric heights of Z1 and Z2 measurement points obtained on the basis of prelabelled measures were correlated on the Fig. 5. The accuracy of obtained heights from the satellite levelling measurement for all scrutinized geoid models equals $7 \mathrm{~mm}$ and $8 \mathrm{~mm}$, for Z1 and Z2 points respectively. The accuracy of determining the height in compliance with the classical measurement is significantly higher and for $\mathrm{Z} 1$ and $\mathrm{Z} 2$ points it was respectively equal $0.13 \mathrm{~mm}$ and $0.12 \mathrm{~mm}$.

\section{Discussion and conclusion}

The main objective of this study was to collate the orthometric heights of measurement points as well as the accuracy of these heights depending on the established geoid model and measurement method. On the grounds of results presented in the Chapter 4. the following conclusion referring to the established objective may be drawn:

- the analysis of obtained data from satellite levelling in regard to measuring point $\mathrm{Z} 1$ enables to purport minor discrepancy between orthometric heights for the selected geoid models being within the range $2.3 \mathrm{~cm}-4.5 \mathrm{~cm}$. It should be also emphasized that for 6 of studied models the results differ by the height not exceeding $3 \mathrm{~cm}$. Protrusive heights are the heights elicited for the models of GEOIDPOL2008CN as well as PL-GEOID-2011 with regard to the analysed point. The height obtained for the oldest among the selected models is nearly $18 \mathrm{~cm}$ smaller than the height relating to the newest models of equipotential surface, therefore it significantly diverges from the other results. The analysed dataset is featured by standard deviation $\sigma$ $=0.07$ and mean value $\mathrm{Hs}=120.531 \mathrm{~m}$. Analogous conclusions may be drawn by analysing the results obtained from satellite levelling for the second measuring point. In this case as well, the protrusive heights have been reached for the models of GEOIDPOL-2008CN, OSU-91 and PL-GEOID2011. The above-mentioned statistical measures for the point $\mathrm{Z} 2$ are respectively equal $\sigma=0.07$ and $\mathrm{Hs}=120.595 \mathrm{~m}$;

- the results obtained from the classical precise levelling of the point $\mathrm{Z1}$ are approximate to those of satellite levelling. The discrepancies between orthometric heights for the particular geoid models and heights obtained by the second technique that was chosen are within the range: $0.4 \mathrm{~cm}-3.4 \mathrm{~cm}$. In the case of point $\mathrm{Z} 2$, no discrepancies of results for both methods were observed. Such a situation can be a result of significant encasing of horizon by a car being in close proximity to the measuring point while effectuating mensuration;

- the accuracy of heights obtained by means of precise levelling method is significantly higher than the heights obtained by means of satellite levelling. The accuracy of heights determined from satellite measurement regardless of the chosen geoid model have not undergone any changes. The result may be an outcome of minor and mutual distance of measurement points;

- the results of these studies imply the necessity of the enhancement of measurements in the future for greater amount of points. It is strictly suggested that the analysed points should be located in considerably greater distance from each other, preferably on the areas of diversified terrain. Measurement executed according to the suggested recommendation may provide noteworthy conclusion on the accuracy of satellite levelling for various geoid models;

- the fact that studies were conducted two years ago should be emphasized. According to the Author, all available measurement equipment as well as software at present definitely enables wider analysis of the accuracy of satellite levelling. There is no doubt that since conducting the measurement, many new geoid models appeared and these should be included within the studies.

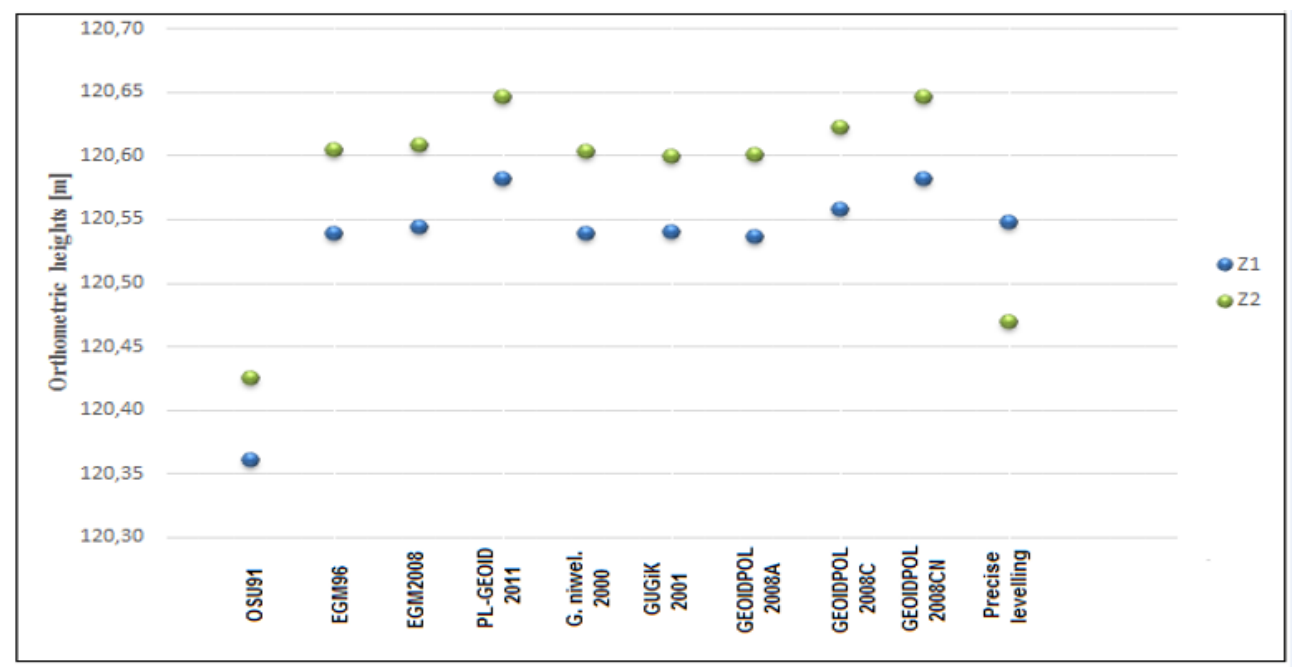

Fig. 5. Orthometric heights of measurement points $\mathrm{Z} 1$ and $\mathrm{Z} 2$ for global and regional geoid models obtained from measurements of satellite levelling and precise levelling. 


\section{References}

1. K. Czarnecki, Geodezja wspótczesna w zarysie (1994, in Polish)

2. G. Seeber, Satellite Geodesy (2003)

3. A. Jagielski, Geodezja I (2005, in Polish)

4. ASG-EUPOS, Uktady odniesienia, (2015), website address: $\quad$ http://www.asgeupos.pl/index. php?wpg_type=tech_rf\&sub $=$ geoid

5. M.G. Sideris, Geoid determination (2005)

6. G. Kloch and J. Kryński, Prace IGiK 54, 5-25 (2008, in Polish)

7. D. Piętka, Implementacja Europejskiego modelu Quasi-geoidy Grawimetrycznej EGG2008 na obszarze Polski (2014, in Polish)

8. A. Łyszkowicz, Przegląd Geologiczny, 4 (1995)

9. Instytut Geodezji i Kartografii (IGiK), Modelowanie geoidy, (2015), website address: http://www.igik.edu.pl/pl/geodezja-i geodynam ikamodelowanie-geoidy

10. Instytut Geodezji i Kartografii (IGiK), Krajowe i regionalne modele geoidy, (2015), website address: http://www.igik.edu.pl/pl/geodezja-i-geodynamikamodele-geoidy1.

11. R. Kadaj, GEOIDPOL-2008 jako centymetrowej dokładności model quasigeoidy dla obszaru Polski oparty na globalnym modelu geopotencjalnym EGM-2008 $i$ polskich trójwymiarowych sieciach satelitarno niwelacyjnych EUVN, EUREF-POL $i$ POLREF, website address: http://www.geonet.net.pl/ images/2012_05_geoidpol_2008.pdf

12. R. Kadaj, Algorytm opracowania modelu PL-geoid 2011, (2015), website address: http://www.rogopen.gik.pw.edu.pl/phocadownload/ Gryb_2014/Sesja\%205A/Kadaj_Algorytm\%20oprac owania\%20modelu\%20PL-geoid2011.pdf

13. International Service for Geoid (ISG), Global Gravity Field Models, (2016), website address: http://icgem.gfz-potsdam.de/tom_longtime

14. Official webpage of the NASA and NIMA, EGM96, (2016), website address: http://cddis .gsfc.nasa.gov/926/egm96/egm96.html

15. N. Pavlis, R. Rapp, Y. Wang, The Ohio State 1991 Geopotential and Sea Surface Topography Harmonic Coefficient Models (NTRS, 1991)

16. J. Lamparski, NAVSTAR GPS. Od teorii do praktyki (2001, in Polish)

17. Rozporządzenie Ministra Administracji i Cyfryzacji z dnia 14 lutego 2012 r. w osnów geodezyjnych, grawimetrycznych i magnetycznych (Dz. U. z 2012 r., poz. 352)

18. Rozporządzenie Ministra Spraw Wewnętrznych i Administracji z dnia 9 listopada 2011 r. w sprawie standardów technicznych wykonywania geodezyjnych pomiarów sytuacyjnych i wysokościowych oraz opracowywania i przekazywania wyników tych pomiarów do państwowego zasobu geodezyjnego i kartograficznego (Dz. U. z 2011 r., Nr 263, poz. 1572

19. F. Kłosowski, Transmutation Geoid v. 0.5.4, (2015), website address: http://www.geoida.pl/ sprzet_geodezyjny,produkt,126.htm 